\title{
A change of profile?
}

\author{
A. K. Higgins \\ Grønlands Geologiske Undersøgelse, Øster Voldgade 10, DK-1350 København K, Danmark.
}

Geologists wòrking in East Greenland have introduced a number of place names derived from their measurement of sedimentary sections (or profiles) in well exposed rock sequences. These names include: Profilbjerg, Profildal, Profilfjeldet, Profile Ravine and another Profilbjerg. The first three of these have been approved by the Greenland Place Names Committee, and of these two are type localities for stratigraphical units; the latter two have not been approved, and have no official status.

Profilbjerg is a mountain in northern Scoresby Land, $9 \mathrm{~km}$ west of Mesters Vig. The name arose during detailed lead prospecting in 1948-49, and was subsequently approved. Detailed topographic maps show the present spelling, but in some early geological publications (e.g. Witzig, 1954) it appeared in the form Profilbjarg. Kempter (1961) subsequently named one of the units of the Carboniferous-Permian sequence the 'Profilbjærg-Schichtglied'; in the revised terminology of Perch-Nielsen et al. (1972), this becomes the Profilbjerg Member of the Mesters Vig Formation.

Profilbjerg has also been used for the $950 \mathrm{~m}$ high peak south of Lille Cirkusbjerg in southern Wegener Halvø. The name has never been approved for this mountain, and its location only $67 \mathrm{~km}$ south-east of the mountain of the same name near Mesters Vig makes its official adoption in the future improbable. The term appears to have been introduced by Grasmück \& Trümpy (1969) in their description of 1958 field work in Wegener Halvø. Haller (1971) used the name on one of his geological maps, Birkenmajer (1977) referred to it as the locality where he collected Upper Permian reworked fossils in Lower Triassic rocks, and Fedorowski (1982) noted it as the site of collections of Callophyllum profundum made by Birkenmajer. To avoid confusion with the approved locality Profilbjerg near Mesters Vig, use of the same name for a mountain in Wegener Halvø should be avoided.

Profildal was used in the early 1970s by GGU geologists for a valley in Renland, east of Rypefjord. The name is approved, but so far has only been used as a reference locality on geological maps.

Profile Ravine has been used for a small ravine on the south side of Sederholm Bjerg, central Gauss Halvø. It was introduced during the 1931-34 Treårsexpedition by G. Säve-Söderbergh, and used as a reference locality by Johansson (1935) and Stensiö (1948). This name, and several others used for minor features in the same region, have never been approved.

Profilfjeldet is a mountain on the north side of Sødalen, Kronprins Christian Land. The name was given by Eigil Nielsen who studied geological sections here during the 1938-39 Dansk Nordøstgrønlands Expedition (Nielsen, 1941), and has approved status. A sequence studied by Nielsen at Profilfjeldet was described by Fränkl (1954) as the 'Profilfjeldet Schiefer' or 'Profilfjeldet Shales', and subsequently by Scrutton (1975) as the 'Profilfjeldet Formation'. Hurst \& Surlyk (1982) redefined the sequence as the Profilfjeldet Member, a unit of the Silurian Lauge Koch Land Formation of the Peary Land Group.

\section{References}

Birkenmajer, K. 1977: Erosional unconformity at the base of marine Lower Triassic at Wegener Halvø, central East Greenland. Rapp. Grønlands geol. Unders. 85, 103-107.

Fedorowski, J. 1982: Some rugose corals from the Upper Permian of East Greenland. Rapp. Grønlands geol. Unders. 108, 71-91.

Fränkl, E. 1954: Vorläufige Mitteilung über die Geologie von Kronprins Christians Land (NE-Grönland). Meddr Grønland 116(2), $85 \mathrm{pp}$.

Grasmück, K. \& Trümpy, R. 1969: Triassic stratigraphy and general geology of the country around Fleming Fjord (East Greenland). Meddr Grønland 168(2), 5-71.

Haller, J. 1971: Geology of the East Greenland Caledonides, 413 pp. London \& New York: Interscience Publishers.

Hurst, J. M. \& Surlyk, F. 1982: Stratigraphy of the Silurian turbidite sequence of North Greenland. Bull. Grønlands geol. Unders. 145, $121 \mathrm{pp}$.

Johansson, A. E. V. 1935: Upper Devonian fossiliferous localities in Parallel Valley on Gauss Peninsula, East Greenland. Meddr Grønland 96(3), $37 \mathrm{pp.}$

Kempter, E. 1961: Die jungpaläozoischen Sedimente von Süd Scoresby Land. Meddr Grønland 164(1), 123 pp.

Nielsen, E. 1941: Remarks on the map and the geology of Kronprins Christians Land. Meddr Grønland 126(2), 35 pp.

Perch-Nielsen, K., Bromley, R. G., Birkenmajer, K \& Aellen, M. 1972: Field observations in Palaeozoic and Mesozoic sediments of Scoresby Land and northern Jameson Land. Rapp. Grønlands geol. Unders. 48, $39-59$.

Scrutton, C. T. 1975: Corals and stromatoporoids from the Ordovician and Silurian of Kronprins Christian Land, Northeast Greenland. Meddr Grønland 171(4), 43 pp.

Stensiö, E. A. 1948: On the Placodermi of the Upper Devonian of East Greenland. II. Meddr Grønland 139, $622 \mathrm{pp}$.

Witzig, E. 1954: Stratigraphische und tektonische Beobachtungen in der Mesters Vig-Region (Scoresbyland, Nordostgrönland). Meddr Grønland 72, II (5), $26 \mathrm{pp}$. 